\title{
MUCOPOLYSACCHARIDES IN SYNOVIAL FLUID* EFFECT OF ASPIRIN AND INDOMETHACIN ON HYALURONIC ACID
}

\author{
BY \\ P. J. L. HOLT, $\uparrow$ M. J. HOW, V. J. W. LONG, AND C. F. HAWKINS \\ The Medical School and Chemistry Department, University of Birmingham, Edgbaston, Birmingham
}

Intra-articular inflammation is associated with a reduction in viscosity of synovial fluid which is due to changes in hyaluronic acid rather than in the protein component of the fluid (Kulonen, 1951; Sundblad, 1953). Hyaluronic acid is a polymer of molecular weight greater than $1 \times 10^{6}$ made up from repeating units of $N$-acetyl-D-glucosamine and D-glucuronic acid. It is present in concentrations of about $0.1 \mathrm{~g}$. per cent. or less in rheumatoid synovial fluids, compared with $0.3 \mathrm{~g}$. per cent. in normal fluids. Synovial fluid shows anomalous viscosity, i.e. the viscosity decreases with increasing rate of shear, typical of a non-Newtonian fluid. The relative viscosity of a solution of synovial fluid, defined as the viscosity of the solution divided by the viscosity of the solvent, decreases with age (Jebens and Monk-Jones, 1959) and that of rheumatoid synovial fluid is usually lower than normal (Ropes, Robertson, Rossmeisl, Peabody, and Bauer, 1947; Ragan and Meyer, 1949). However, only slight reductions have been found when normal and rheumatoid fluids have been diluted to the same low concentration $(0.06 \mathrm{~g}$. per cent.) of hyaluronic acid (Hamerman and Schuster, 1958); this suggests that it is the amount rather than the nature of the hyaluronic acid which determines the relative viscosity. Measurements of intrinsic viscosity, determined by extrapolation of the specific viscosity (i.e. relative viscosity -1 ) to zero concentration of solute, and anomalous viscosity give a more accurate picture of the state of hyaluronic acid in solution. The lower values of both these parameters for rheumatoid fluids have been attributed to a low mean degree of polymerization of hyaluronic acid in rheumatoid disease (Seppälä, 1964; Brimacombe and Webber, 1964). Changes similar to those found in

*Presented in part at a meeting of the Heberden Society on March 25, 1966. For discussion see Ann. rheum. Dis. (1966), 25, 473.

†Present address: Department of Medicine, Royal Post-graduate Medical School, London. rheumatoid fluid are obtained by enzymic depolymerization of hyaluronic acid (Barker, Bayyuk, 을 Brimacombe, Hawkins, and Stacey, 1963), andmeasuring the degree of polymerization of synovial3 hyaluronic acid might be expected to be a measure of inflammatory activity.

The method of turbidimetric titration (Morey and Tamblyn, 1945; Harris and Miller, 1951), used to determine the distribution of molecular size ino polymers, was developed by Barker and others (1963) to fingerprint small amounts (approximately $1 \mathrm{mg}$.) of hyaluronic acid from normal and pathological $\frac{0}{\odot}$

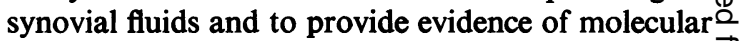
size and degree of homogeneity. Addition of the $\overrightarrow{\overrightarrow{0}}$ detergent cetyl pyridinium chloride to a dilute ${ }^{3}$ deproteinized solution of hyaluronic acid produces a colloidal suspension, the turbidity of which can be? measured by its optical density. Solubility of the colloidal suspension in salt solutions depends in part $\frac{\text {. }}{5}$ on the molecular size of the polymers, and is greater 3 . for smaller molecular weight polymers. Re-solution of the suspension, with a decrease of optical density, occurs with smaller molecules, i.e. if the hyaluronic acid is depolymerized.

Two patterns of turbidity curves are obtained $?$ with synovial hyaluronic acid (Figs 1 and 2, opposite). Addition of detergent causes an initial rapid increase $N$ in optical density, after which a slowly increasing $N$ turbidity is obtained with normal fiuids, whereas a N decrease in turbidity is observed with hyaluronic ${ }_{\sigma}^{\omega}$ acid from the synovial fluid of inflamed joints. Barker and others (1963) considered that the molecular size of hyaluronic acid is the predominant ${ }_{\infty}$ factor in determining the shape of the turbidity ${ }_{7}^{+}$ curve. Generally, the percentage of detergent $\frac{0}{0}$ necessary to produce maximal turbidity decreased $\vec{\nabla}$ with increased depolymerization of the hyaluronic $\frac{\text { ? }}{?}$ acid. The results of turbidimetric titration studies $\varrho$ of normal and rheumatoid synovial fluids were in 
good agreement with parallel studies of the intrinsic viscosities of the fluids. Chemical and enzymic degradation of hyaluronic acid from rheumatoid synovial fluid showed conclusively (Barker, Bayyuk, Brimacombe, Hawkins, and Stacey, 1964) that it has the same molecular structure though a shorter polymer length than hyaluronic acid from "normal" fluids obtained during menisectomy, or from traumatic effusions. Changes in the degree of polymerization of human synovial hyaluronic acid have in this study been used to assess the effects of aspirin and indomethacin in the treatment of various forms of arthritis.

\section{Material and Methods}

57 samples of synovial fluid obtained from thirty patients were studied. Most of the aspirations were performed for diagnostic or therapeutic purposes; in the other cases the procedure was explained and the consent of the patient obtained. All patients having repeated joint aspirations were admitted to hospital and kept under standard conditions of activity.

Aspirin was given in doses of 4-5 g./day orally, and indomethacin in doses varying from 75 to $100 \mathrm{mg}$./day orally or in suppositories. Samples of synovial fluid were aspirated from knee joints and cellular debris was removed by centrifuging for $20 \mathrm{~min}$. at $1,000 \mathrm{G}$; the fluid was stored in sterile bottles at $-25^{\circ} \mathrm{C}$.

Hyaluronic acid was isolated from synovial fluid by digestion of the protein component with the proteolytic enzyme, pronase, and fractionation of the digest, according to molecular size, on Sephadex G 200 (Barker and others, 1963; Barker and Young, 1966).

A solution $(1 \mathrm{mg} . / \mathrm{ml}$.) of Pronase $\mathrm{P}(\mathrm{K}$. and $\mathrm{K}$. Organics Ltd.) in $\mathbf{0 . 1} \mathbf{M}$-phosphate buffer, $\mathrm{pH}$ 7, containing a trace of calcium chloride and saturated with chloroform, was sterilized by passage through a Hemming filter and mixed with synovial fluid (approximately onehalf volume). After centrifugation for $10 \mathrm{~min}$. at 35,000

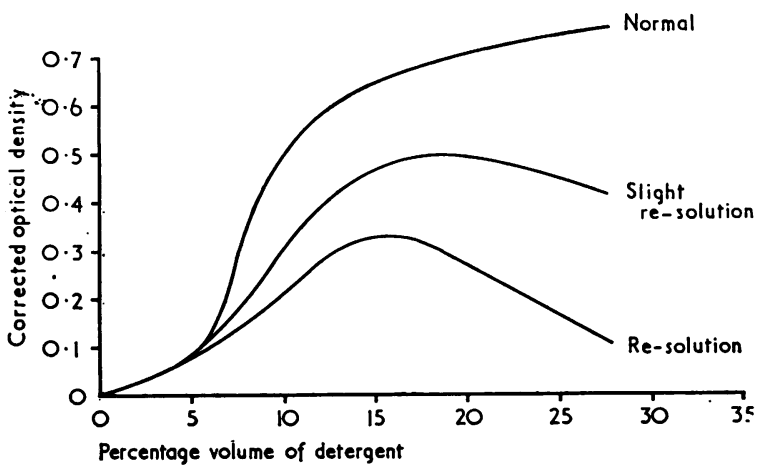

Fig. 1.-Types of turbidity curve obtained with synovial hyaluronic acid of varying degrees of depolymerization (diagrammatic).
$\mathrm{G}$ and $15^{\circ} \mathrm{C}$., the supernatant was transferred to a sterile dialysis apparatus (Chelton and James, 1963) and dialysed under aseptic conditions at $37^{\circ} \mathrm{C}$. for a total of 36 hours against two changes of phosphate buffer. The digest was fractionated on a column of Sephadex G $200(2 \cdot 4 \times$ $45 \mathrm{~cm}$.) equilibrated with phosphate buffer, and eluted with the same buffer at $15-20 \mathrm{ml} / \mathrm{hr}$. The optical density at $280 \mathrm{~m} \mu$ of each fraction $(5 \mathrm{ml}$.) was determined, and fractions were also scanned for protein by the ninhydrin assay of Moore and Stein (1948). The fractions were assayed colorimetrically for hexuronic acid (to identify hyaluronic acid-containing fractions) by a modification (Gregory, 1960) of the Dische (1947) carbazole reaction. A calibration curve was prepared using a standard solution of D-glucurono- $\gamma$-lactone. Optical densities were determined using a Unicam SP 500 or SP 1300 spectrophotometer, and in some cases the absorption spectrum in the range $300-700 \mathrm{~cm}^{-1}$ was determined using a Unicam SP 800 spectrophotometer.

Fractions giving a positive reaction for uronic acid were bulked, dialysed exhaustively against distilled water, centrifuged, and filtered through a No. 3 sintered glass filter. An aliquot, containing $200-400 \mu \mathrm{g}$. hyaluronic acid as determined by the carbazole reaction, was diluted to $35 \mathrm{ml}$. with filtered distilled water and titrated turbidimetrically with a filtered solution of 0.05 per cent. cetylpyridinium chloride as previously described (Barker and others, 1963). The optical density of the solution, corrected for dilution, was plotted against the volume of detergent (non-solvent) expressed as a percentage of the total volume.
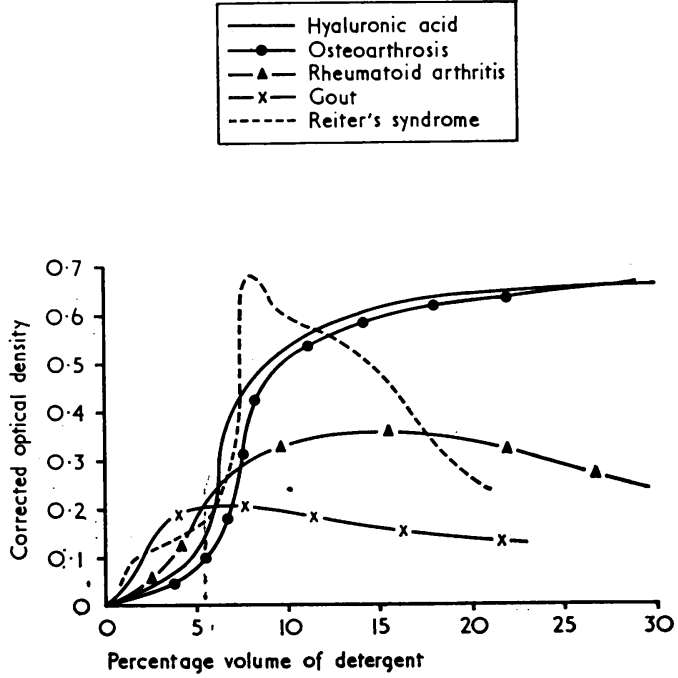

Fig. 2.-Typical turbidity curves obtained by using synovial fluid from various types of arthritis. 


\section{Results}

Experiments were first designed to assess the effects of various procedures on hyaluronic acid within the joint. In Cases 1 to 4 (Table) polymerized hyaluronic acid remained unchanged after aspiration. (In Case 3 a low dose of aspirin $1 \cdot 2$ g./day has been ignored.) More important, in Cases 5 to 10 depolymerized hyaluronic acid was unaltered by aspiration and rest in bed for up to 16 days (Fig. 3). No attempt was made to drain the joint, and these results show that aspiration of a sample (10-20 ml.) of fluid left the hyaluronic acid unaffected. Synovial biopsies were performed using a small needle (Williamson and Holt, 1966a) and this had no effect. Fluid that was blood-stained or showed evidence of previous bleeding was discarded. As patients can seldom tolerate withdrawal of all treatment, paracetamol (usually $4 \mathrm{~g}$. daily) was used as an analgesic, since it was found not to alter the shape of the turbidity curve. Results (Table) confirmed that depolymerized hyaluronic acid occurred in the joints of those with inflammatory forms of arthritis, such as rheumatoid arthritis, $\frac{\sigma}{\omega}$. psoriatic arthritis, and the arthritis of ulcerative colitis or Crohn's disease. Occasionally, normal hyaluronic acid was found in patients with these 0 diseases and it was assumed that the arthritis in the $\overline{0}$ joint aspirated was quiescent; there was certainly $\frac{\overline{\bar{c}}}{\overline{0}}$

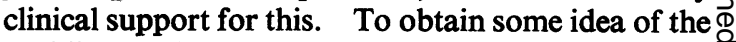
rapidity of alteration of hyaluronic acid in response to inflammation, the treatment of Patient 21 was reduced from prednisone $10 \mathrm{mg}$. and aspirin $2 \cdot 66 \mathrm{~g}$.. to prednisone $5 \mathrm{mg}$. over 24 hours. This caused $\overrightarrow{\vec{H}}$ clinical relapse and a decrease in the degree of ${ }^{\omega}$ polymerization of synovial hyaluronic acid as reflected by the shape of the turbidity curve (Fig. 4). Generally, the reverse change, improvement with. treatment, was slower.

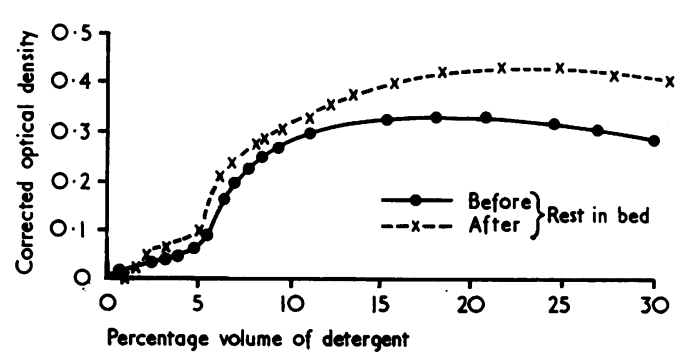

Fig. 3.-Synovial fluid before and after 16 days rest in bed.

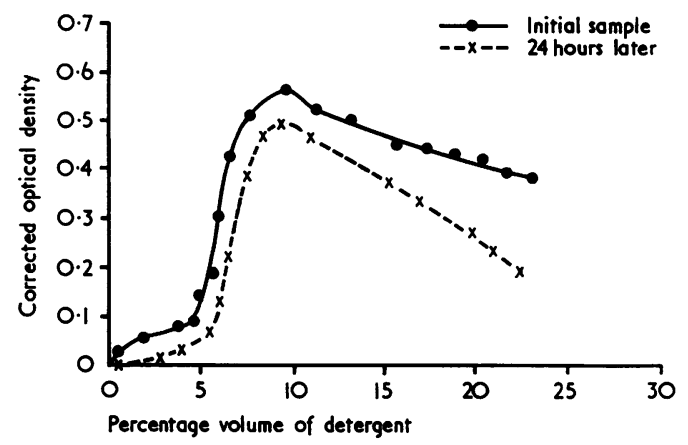

Fig. 4.-Alteration in hyaluronic acid turbidity curve after reduction of prednisone from 10 to $5 \mathrm{mg}$. and stopping aspirin $2.66 \mathrm{~g}$. for a period of 24 hours (Patient 20).

TABLE

CLINICAL PARTICULARS OF THIRTY PATIENTS

\begin{tabular}{|c|c|c|c|c|c|c|c|c|c|}
\hline $\begin{array}{c}\text { Patient } \\
\text { No. }\end{array}$ & Sex & $\begin{array}{c}\text { Age } \\
\text { (yrs) }\end{array}$ & Diagnosis & $\begin{array}{c}\text { Duration } \\
\text { of } \\
\text { Disease } \\
\text { (yrs) }\end{array}$ & $\begin{array}{l}\text { Turbidity } \\
\text { Curve }\end{array}$ & $\begin{array}{c}\text { Interval } \\
\text { between } \\
\text { Aspirations } \\
\text { (days) }\end{array}$ & $\begin{array}{l}\text { Treatment } \\
\text { since } \\
\text { Previous } \\
\text { Aspiration }\end{array}$ & $\underset{(\mathrm{mm} . / 1 \mathrm{hr})}{\mathrm{ESR}}$ & $\begin{array}{c}\text { Clinical } \\
\text { Observations }\end{array}$ \\
\hline 1 & $\mathbf{F}$ & 60 & OA & 30 & $\begin{array}{l}\text { Normal } \\
\text { Normal }\end{array}$ & 2 & Rest in bed & 9* & $\begin{array}{l}\text { Symptomless } \\
\text { effusion }\end{array}$ \\
\hline 2 & $\mathbf{F}$ & 45 & $\begin{array}{l}\text { Psoriatic } \\
\text { arthritis }\end{array}$ & 10 & $\begin{array}{l}\text { Normal } \\
\text { Normal }\end{array}$ & 6 & Rest in bed & $24 \dagger$ & $\begin{array}{l}\text { Symptomless } \\
\text { effusion }\end{array}$ \\
\hline 3 & $\mathbf{F}$ & 60 & RA & 30 & $\begin{array}{l}\text { Normal } \\
\text { Normal }\end{array}$ & 2 & Rest in bed & $30 *$ & $\begin{array}{l}\text { Symptomless } \\
\text { effusion }\end{array}$ \\
\hline 4 & $\mathbf{M}$ & 28 & $\mathbf{R A}$ & 15 & $\begin{array}{l}\text { Normal } \\
\text { Normal }\end{array}$ & 2 & Rest in bed & $4 t$ & $\begin{array}{l}\text { Symptomless } \\
\text { effusion }\end{array}$ \\
\hline 5 & $\mathbf{F}$ & 50 & RA & 3 & $\begin{array}{l}\text { Re-solution } \\
\text { Re-solution } \\
\text { Slight re-solution }\end{array}$ & $\begin{array}{l}1 \\
7\end{array}$ & $\begin{array}{l}\text { High dosage } \\
\text { aspirin }\end{array}$ & $88 *$ & $\begin{array}{l}\text { Severe } \\
\text { Slight improvement }\end{array}$ \\
\hline
\end{tabular}


Table I (continued)

\begin{tabular}{|c|c|c|c|c|c|c|c|c|c|}
\hline $\begin{array}{c}\text { Patient } \\
\text { No. }\end{array}$ & Sex & $\begin{array}{l}\text { Age } \\
\text { (yrs) }\end{array}$ & Diagnosis & $\begin{array}{c}\text { Duration } \\
\text { of } \\
\text { Disease } \\
\text { (yrs) }\end{array}$ & $\begin{array}{l}\text { Turbidity } \\
\text { Curve }\end{array}$ & $\begin{array}{l}\text { Interval } \\
\text { between } \\
\text { Aspirations } \\
\text { (days) }\end{array}$ & $\begin{array}{l}\text { Treatment } \\
\text { since } \\
\text { Previous } \\
\text { Aspiration }\end{array}$ & $\underset{(\mathrm{mm} \cdot / 1 \mathrm{hr})}{\mathrm{ESR}}$ & $\begin{array}{c}\text { Clinical } \\
\text { Observations }\end{array}$ \\
\hline 6 & $\mathbf{F}$ & 43 & $\mathbf{R A}$ & 8 & $\begin{array}{l}\text { Re-solution } \\
\text { Re-solution } \\
\text { Slight re-solution }\end{array}$ & $\begin{array}{l}16 \\
18\end{array}$ & Indomethacin & $52 \dagger$ & $\begin{array}{l}\text { Slight improvement } \\
\text { Relapse on placebo }\end{array}$ \\
\hline 7 & $\mathbf{M}$ & 57 & $\mathbf{R A}$ & 16 & $\begin{array}{l}\text { Re-solution } \\
\text { Re-solution } \\
\text { Normal }\end{array}$ & $\begin{array}{l}3 \\
4\end{array}$ & Indomethacin & $28+$ & $\begin{array}{l}\text { Moderate } \\
\text { improvement }\end{array}$ \\
\hline 8 & $\mathbf{F}$ & 46 & RA & 2 & $\begin{array}{l}\text { Re-solution } \\
\text { Re-solution }\end{array}$ & 3 & None & & \\
\hline 9 & $\mathbf{F}$ & 60 & RA & 14 & $\begin{array}{l}\text { Re-solution } \\
\text { Re-solution }\end{array}$ & 3 & None & & \\
\hline 10 & $\mathbf{M}$ & 23 & $\mathbf{R A}$ & $2 / 12$ & $\begin{array}{l}\text { Re-solution } \\
\text { Re-solution } \\
\text { Slight re-solution }\end{array}$ & 2 & $\begin{array}{l}\text { High dosage } \\
\text { aspirin }\end{array}$ & $52 \dagger$ & $\begin{array}{l}\text { Severe initial attack } \\
\text { Slight improvement }\end{array}$ \\
\hline 11 & $\mathbf{F}$ & 54 & $\mathbf{O A}$ & 6 & Normal & 一 & None & & \\
\hline 12 & $\mathbf{M}$ & 54 & $\begin{array}{l}\text { Psoriatic } \\
\text { arthritis }\end{array}$ & $2 / 12$ & Slight re-solution & 一 & None & $44^{*}$ & $\begin{array}{l}\text { Moderately severe } \\
\text { initial attack }\end{array}$ \\
\hline 13 & $\mathbf{M}$ & 21 & $\begin{array}{l}\text { Reiter's } \\
\text { syndrome }\end{array}$ & 6 & Normal & - & None & & $\begin{array}{l}\text { Symptomless effusion } \\
\text { after acute attack }\end{array}$ \\
\hline 14 & $\mathbf{M}$ & 52 & $\begin{array}{l}\text { Reiter's } \\
\text { syndrome }\end{array}$ & $1 / 4$ & Re-solution & - & None & & Severe initial attack \\
\hline 15 & $\mathbf{M}$ & 40 & $\begin{array}{l}\text { Reiter's } \\
\text { syndrome }\end{array}$ & $1 / 12$ & Re-solution & - & None & & Severe initial attack \\
\hline 16 & $\mathbf{M}$ & 42 & Gout & 10 & Normal & 一 & None & $14 \dagger$ & $\begin{array}{l}\text { Mild post-acute } \\
\text { attack }\end{array}$ \\
\hline 17 & $\mathbf{M}$ & 66 & Gout & 18 & Re-solution & - & None & & Acute attack \\
\hline 18 & $\mathbf{F}$ & 52 & Scleroderma & 1 & $\begin{array}{l}\text { Slight re-solution } \\
\text { Normal }\end{array}$ & 7 & Indomethacin & & Mild \\
\hline 19 & $\mathbf{F}$ & 20 & $\begin{array}{l}\text { Crohn's } \\
\text { disease }\end{array}$ & 4 & Slight re-solution & - & None & & Mild \\
\hline 20 & $\mathbf{M}$ & 28 & $\begin{array}{l}\text { Ulcerative } \\
\text { colitis }\end{array}$ & 5 & Slight re-solution & 一 & None & & Transient effusion \\
\hline 21 & $\mathbf{M}$ & 24 & RA & 6 & $\begin{array}{l}\text { Slight re-solution } \\
\text { Re-solution }\end{array}$ & 1 & $\begin{array}{l}\text { Dose of pred- } \\
\text { nisone reduced }\end{array}$ & & \\
\hline 22 & $\mathbf{M}$ & 60 & RA & $2 \frac{1}{2}$ & $\begin{array}{l}\text { Re-solution } \\
\text { Slight re-solution }\end{array}$ & 7 & $\begin{array}{l}\text { High dosage } \\
\text { aspirin }\end{array}$ & $115^{*}$ & Severe \\
\hline 23 & $\mathbf{F}$ & 45 & RA & 10 & $\begin{array}{l}\text { Re-solution } \\
\text { Re-solution }\end{array}$ & 7 & $\begin{array}{l}\text { High dosage } \\
\text { aspirin }\end{array}$ & $55^{*}$ & $\begin{array}{l}\text { Moderately severe } \\
\text { No change }\end{array}$ \\
\hline 24 & $\mathbf{M}$ & 60 & RA & 3 & $\begin{array}{l}\text { Re-solution } \\
\text { Re-solution } \\
\text { Slight re-solution }\end{array}$ & $\begin{array}{l}5 \\
7\end{array}$ & $\begin{array}{l}\text { High dosage } \\
\text { aspirin }\end{array}$ & $87^{*}$ & $\begin{array}{l}\text { Moderately severe } \\
\text { Slight improvement }\end{array}$ \\
\hline 25 & $\mathbf{F}$ & 72 & $\mathbf{R A}$ and $\mathbf{O A}$ & 7 & $\begin{array}{l}\text { Re-solution } \\
\text { Normal }\end{array}$ & 7 & $\begin{array}{l}\text { High dosage } \\
\text { aspirin }\end{array}$ & $10+$ & \\
\hline 26 & $\mathbf{M}$ & 64 & RA & 20 & $\begin{array}{l}\text { Re-solution } \\
\text { Re-solution } \\
\text { Slight re-solution }\end{array}$ & $\begin{array}{l}7 \\
7\end{array}$ & $\begin{array}{l}\text { Aspirin } \\
\text { Indomethacin }\end{array}$ & $57^{*}$ & $\begin{array}{l}\text { Moderately severe } \\
\text { Slight benefit }\end{array}$ \\
\hline 27 & $\mathbf{F}$ & 39 & $\mathbf{R A}$ & 10 & $\begin{array}{l}\text { Re-solution } \\
\text { Normal }\end{array}$ & 7 & Indomethacin & $43^{*}$ & $\begin{array}{l}\text { Moderately severe } \\
\text { Good response on } \\
\text { indomethacin } \\
\text { Relapse on placebo }\end{array}$ \\
\hline 28 & $\mathbf{F}$ & 62 & RA & 8 & $\begin{array}{l}\text { Re-solution } \\
\text { Normal }\end{array}$ & 14 & Indomethacin & & $\begin{array}{l}\text { Moderately severe } \\
\text { Good response }\end{array}$ \\
\hline 29 & $\mathbf{F}$ & 71 & RA & 2 & $\begin{array}{l}\text { Slight re-solution } \\
\text { Normal }\end{array}$ & 10 & Indomethacin & $49+$ & $\begin{array}{l}\text { Moderately severe } \\
\text { Slight improvement }\end{array}$ \\
\hline 30 & $\mathbf{M}$ & 59 & $\begin{array}{l}\text { Psoriatic } \\
\text { arthritis }\end{array}$ & 2 & $\begin{array}{l}\text { Re-solution } \\
\text { Normal }\end{array}$ & 12 & Indomethacin & $16^{*}$ & $\begin{array}{l}\text { Mild } \\
\text { Good response }\end{array}$ \\
\hline
\end{tabular}


The effect of indomethacin alone was tested in seven patients. Clinical response was usually rapid and concomitant improvement in the degree of polymerization of hyaluronic acid was seen convincingly in the first week (for example, Case 28, Fig. 5); all seven showed some improvement both clinically and by turbidity measurement.

The degree of polymerization of synovial hyaluronic acid from five of seven patients was increased by aspirin (for example, Case 25, Fig. 6). Aspirin was slower in its clinical action but also tended to restore the shape of the turbidity curve towards normal, although to a lesser degree than indomethacin.

\section{Discussion}

The shape of the turbidity curve reflects inflammatory activity within the joint, irrespective of the disease process. The cause of the depolymerization of hyaluronic acid is unknown. Lysosomal enzymes are present in excess in both synovial tissue (Luscombe, 1963; Hendry and Carr, 1963) and synovial fluid (Jacox and Feldmahn, 1955; Lehman, Kream, and Brogna, 1964; Caygill and Pitkeathly, 1966) in rheumatoid arthritis. Their presence in synovial fluid may result from destruction of the excess polymorphonuclear leucocytes, or from lymphocytic transformation, a change which can take place within the inflamed joint and may lead to increased lysosome production (Allison and Mallucci, 1964). The anti-inflammatory action of prednisone, indomethacin, and aspirin could then be explained by their action as lysosomal stabilizers, in blocking part of the inflammatory chain reaction at its terminal link. The adrenal glucocorticosteroids stabilize lysosome both in vitro and in vivo (Weissmann and Thomas, 1964). Acetylsalicylic acid has also recently been demonstrated biochemically to stabilize lysosomal membranes in vitro (Miller and Smith, 1966); no direct evidence has been published of lysosomal stabilization due to indomethacin, though inhibition of leucocytic infiltration and suppression of motility have been shown by Phelps and McCarty (1966). Histochemical staining of synovial smears

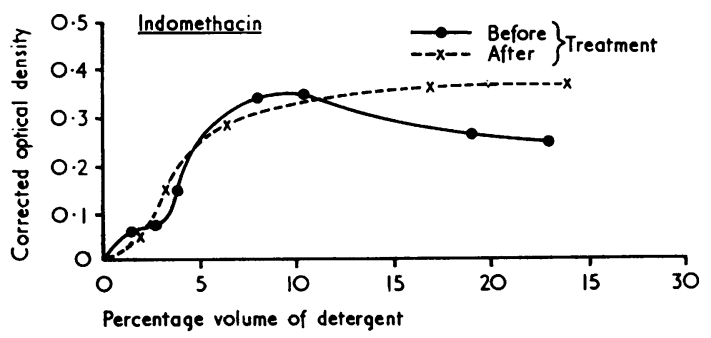

Fig. 5.-Effect of indomethacin on synovial fluid hyaluronic acid (Patient 28). from our patients has shown that all three drugs, $\frac{\subsetneq}{亏}$ predisone, indomethacin, and aspirin, are also $\frac{}{6}$. lysosomal stabilizers in vivo (Williamson and Holt, 1966b). Another possibility is that at the cellular $\overrightarrow{\vec{s}}$ level, indomethacin, salicylates, and hydrocortisone, $\overrightarrow{0}$ which inhibit A.T.P. production (Whitehouse, 1964), $\frac{\bar{\sigma}}{0}$ could reduce hyaluronic acid synthesis and also $\overline{\bar{c}}$. lysosomal activity. There may, however, be other $\widehat{\varnothing}$ reasons for the break-down of hyaluronic acid, and $\mathrm{a}_{0}$ hyaluronidase (exohexosaminidase) has been re- $\infty$ ported in synovial fluid and synovial tissue (Bollet, $\overrightarrow{0}$ Bonner, and Nance, 1963).

Corticosteroids increase polymerization of $\vec{\sigma}$ hyaluronic acid (Barker and others, 1963), and this@ probably explains their effect in increasing the relative, intrinsic, and anomalous viscosity of $v$ synovial fluid by either local or systemic administra-i tion (Bauer, Giansiracusa, and Ropes, 1950; $\stackrel{\sim}{+}$ Sundblad, Egelius, and Jonsson, 1954; Näntö and Seppälä, 1962). Other explanations of their effect ${ }^{\circ}$ are that the less polymerized fraction is eliminated $\vec{z}$ from the joint (Näntö and Seppälä, 1962) or that they have a direct effect on the synthesis of hyaluronic acid in synovial tissue (Jessar, Ganzell, ando Ragan, 1953; Sundblad and others, 1954). However, it is not known whether corticosteroids? reduce the production of imperfectly-formed hyaluronic acid or decrease the rate of enzymico breakdown of normally-formed hyaluronic acid.气 Hyaluronate turnover studies (Sandson, 1966) $\stackrel{\unrhd}{\unrhd}$ suggested a half-life in the normal calf joint of 15 to $\overrightarrow{\vec{P}}$ 24 hours, and that hyaluronic acid, once it is formed, 3 is not degraded in synovial fluid. Similar studies in man might help to answer these questions.

The anti-inflammatory effect of both aspirin and indomethacin has been demonstrated using severale animal models. In man some evidence has been' obtained of an anti-inflammatory effect of aspirin.

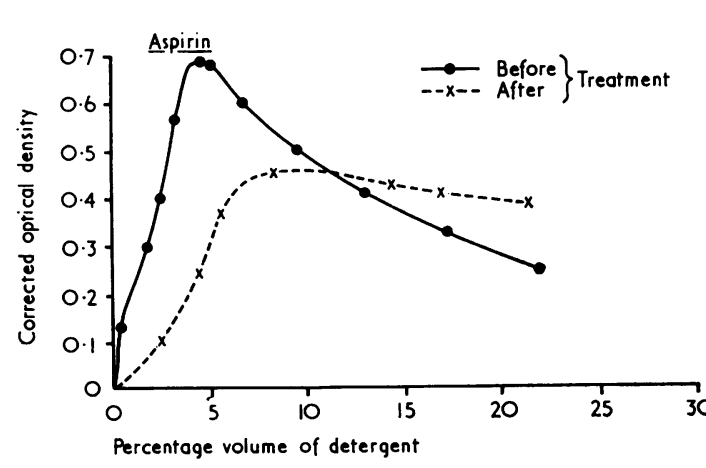

Fig. 6.-Effect of aspirin on synovial fluid hyaluronic acid (Patient 25) 
in crystal-induced arthritis (Steele and McCarty, 1966) and of indomethacin in reducing skin inflammation in response to a variety of irritants (Heimeyer and Heilmeyer, 1965). Circumstantial evidence has also been obtained by noting measurable reduction of finger swelling in rheumatoid arthritics after each drug (Fremont-Smith and Bayles, 1965; Hart and Boardman, 1963). The present study demonstrates biochemically an anti-inflammatory action of both these drugs.

\section{Summary}

(1) Hyaluronic acid in synovial fluid is depoly- merized in untreated inflammatory arthritis irrespective of the aetiology.

(2) A biochemical method of in vivo assessment of anti-inflammatory drugs is discussed.

(3) This method has been used to demonstrate an anti-inflammatory effect of indomethacin and aspirin in man.

The authors thank Prof. M. Stacey, F.R.S., and Dr. S. A. Barker for their interest in this work. Financial support was given by the Arthritis and Rheumatism Council for Research and the Nuffield Rheumatism Research Council.

\section{REFERENCES}

Allison, A. C., and Mallucci, L. (1964). Lancet, 2, 1371 (Lysosomes in dividing cells, with special reference.to lymphocytes).

Barker, S. A., Bayyuk, S. H. I., Brimacombe, J. S., Hawkins, C. F., and Stacey, M. (1963). Clin. chim. Acta, 8, 902 (Fingerprinting the hyaluronic acid component of normal and pathological synovial fluids).

$\left.-,-\frac{-}{-}, \frac{1}{-},-1964\right)$ Ibid., 9, 339 (The structure of the hyaluronic acid component of synovial fluid in rheumatoid arthritis).

synovial fluid by pronase digestion and gel filtration).

Bauer, W., Giansiracusa, J. E., and Ropes, M. W. (1950). Trans. Ass. Amer. Phycns, 63, 76 (The natural course of rheumatoid arthritis and the changes induced by ACTH).

Bollet, A. J., Bonner, W. M., Jr., and Nance, J. L. (1963). J. biol. Chem., 238, 3522 (The presence of hyaluronidase in various mammalian tissues).

Brimacombe, J. S., and Webber, J. (1964). "Mucopolysaccharides". Elsevier, London.

Caygill, J. C., and Pitkeathly, P. A. (1966). Ann. rheum. Dis., 25, 137 (A study of $\beta$-acetylglucosaminase and acid phosphatase in pathological joint fluids).

Chelton, E. T. J., and James, C. G. (1963). Chem. Indust. (Lond.), p. 1077 (A method for aseptic dialysis).

Dische, Z. (1947). J. biol. Chem., 167, 189 (A new specific color reaction of hexuronic acids).

Fremont-Smith, K., and Bayles, T. B. (1965). J. Amer. med. Ass., 192, 1133 (Salicylate therapy in rheumatoid arthritis).

Gregory, J. D. (1960). Arch. Biochem., 89, 157 (The effect of borate on the carbazole reaction).

Hamerman, D., and Schuster, H. (1958). Arthr. and Rheum., 1, 523 (Synovial fluid hyaluronate in rheumatoid arthritis).

Harris, I., and Miller, R. J. G. (1951). J. Polymer Sci., 7, 377 (Molecular weight distribution in polymethyl methacrylate).

Hart, F. Dudley, and Boardman, P. L. (1963). Brit. med. J., 2, 965 (Indomethacin: a new nonsteroid anti-inflammatory agent).

Heimeyer, V., and Heilmeyer (1965). "Proc. XI Int. Congr. Rheumatol.", p. 283. Mar del Plata, Argentina.

Hendry, N. G. C., and Carr, A. J. (1963). Nature (Lond.), 199, 392 (A glycosidase abnormality in synovial membrane in joint disease).

Jacox, R. F., and Feldmahn, A. (1955), J. clin. Invest., 34, 263 (Variations of beta glucuronidase concentration in abnormal human synovial fluid).

Jebens, E. H., and Monk-Jones, M. E. (1959). J. Bone Jt Surg., 41B, 388 (On the viscosity and $\mathrm{pH}$ of synovial fluid and the $\mathrm{pH}$ of blood).

Jessar, R. A., Ganzell, M. A., and Ragan, C. (1953). J. clin. Invest., 32, 480 (The action of hydrocortisone in synovial inflammation).

Kulonen, E. (1951). Acta physiol. scand., 24, Suppl. 88 (Studies on hyaluronic acid and hyaluronidase in the animal organism).

Lehman, M. A., Kream, J., and Brogna, D. (1964). J. Bone Jt Surg., 46A, 1732 (Acid and alkaline phosphatase activity in the serum and synovial fluid of patients with arthritis). 
Luscombe, M. (1963). Nature (Lond.), 197, 1010 (Acid phosphatase and catheptic activity in rheumatoid synovial tissue).

Miller, W. S., and Smith, J. G., Jr. (1966). Proc. Soc. exp. Biol. (N.Y.), 122, 634 (Effect of acetylsalicylic acid on lysosomes).

Moore, S., and Stein, W. H. (1948). J. biol. Chem., 176, 367 (Photometric ninhydrin method for use in the chromatography of amino acids).

Morey, D. R., and Tamblyn, J. W. (1945). J. appl. Phys., 16, 419 (The determination of molecularweight distribution in high polymers by means of solubility limits).

Näntö, V., and Seppälä, P. (1962). Acta path. microbiol. scand., Suppl. 154, p. 235 (Effect of intraarticular hydrocortisone treatment on the macromolecular carbohydrate fractions in the synovial fluid).

Phelps, P., and McCarty, D. J., Jr. (1966). Arthr. and Rheum. (Abstr.), 9, 532 (Suppression of crystalinduced synovitis in canine joints by indomethacin: demonstration of inhibition of leukocytic motility).

Ragan, C., and Meyer, K. (1949). J. clin. Invest., 28, 56 (The hyaluronic acid of synovial fluid in rheumatoid arthritis).

Ropes, M. W., Robertson, W. V. B., Rossmeisl, E. C., Peabody, R. B., and Bauer, W. (1947). Acta med. scand., 128, Suppl. 196, p. 700 (Synovial fluid mucin).

Sandson, J. (1966). Arthr. and Rheum., 9, 874 (Turnover of hyaluronate protein in synovial fluid; Abstr.).

Seppälä, P. (1964). Scand. J. clin. Lab. Invest., 16, Suppl. 79 (Synovial fluid in rheumatoid arthritis).

Steele, A. D., and McCarty, D. J., Jr. (1966). Arthr. and Rheum., 9, 430 (An experimental model of acute inflammation in man).

Sundblad, L. (1953). Acta Soc. Med. upsalien., 58, 113 (Studies on hyaluronic acid in synovial fluids).

—, Egelius, N., and Jonsson, E. (1954). Scand. J. clin. Lab. Invest., 6, 295 (Action of hydrocortisone on the hyaluronic acid of joint fluids in rheumatoid arthritis).

Weissmann, G., and Thomas, L. (1964). Rec. Progr. Hormone Res., 20, 215 (The effects of corticosteroids upon connective tissue and lysosomes).

Whitehouse, M. W. (1964). Acta rheum. scand., Suppl. 8, p. 5 (Some biochemical properties and a possible mode of action of antirheumatic drugs).

Williamson, N., and Holt, L. P. J. (1966a). Lancet, 1, 799 (A synovial biopsy needle).

,$--(1966 \mathrm{~b})$. In preparation.

Les mucopolysaccharides dans le liquide synovial

L'effet de l'aspirine et de l'indométhacine sur l'acide hyaluronique

RÉSUMÉ

(1) L'acide hyaluronique dans le liquide synovial est dépolymérisé dans les cas d'arthrite inflammatoire non traités, quelle que soit son étiologie.

(2) On discute une méthode biochimique d'évaluation in vivo des médicaments anti-inflammatoires.

(3) On s'est servi de cette méthode pour démontrer l'effet anti-inflammatoire de l'indométhacine et de l'aspirine chez l'homme.
Los mucopolisacaridos en el líquido sinovial El efecto de la aspirina $y$ de la indometacina sobre el ácido hialurónico

\section{SUMARIO}

(1) El ácido hialurónico en el líquido sinovial se ve depolimerizado en los casos de artritis inflamatoria sin 3 tratar, cualquiera sea la etiología.

(2) Se discute un método bioquímico de valoración in vivo de los productos anti-inflamatorios.

(3) Se empleó este método para demostrar el efectoo anti inflamatorio de la indometacina y de la aspirina en en el hombre. 